Çanakkale Araştırmaları Türk Yıllığı

Yll: 13, Bahar 2015, Sayı: 18, ss. 447-464, 100. Yil

\title{
İtilaf Devletlerinin Çanakkale'yi Tahliyesinin Türk Basınına Yansımaları
}

\author{
Mücahit ÖZÇELIK*
}

$\ddot{O} z$

Türk kamuoyu, Birinci Dünya Savaşı'nın ve Osmanlı Devletinin kaderini yakından ilgilendiren Çanakkale Cephesi'yle ilgili gelişmeleri anbean takip etmiştir. Çanakkale Cephesi'nde başarılı olamayacağını anlayan İngilizler tahliye kararı almışlardır. Türk ordusu İngilizlerin Arıburnu ve Anafartalar'dan kademeli olarak gerçekleştirdiği tahliyeyi fark edememiştir. İngilizlerin Seddülbahir’i tahliyesi ise daha sıkıntılı olmuş ve geride önemli miktarda silah, cephane, gıda maddesi, giyim eşyası, ilaç, ulaşım ve haberleşme araçları bırakarak neredeyse sadece askerlerini çekebilmiştir. İngilizlerin savaş gemileriyle sürekli Türk bölgelerini bombalaması tahliyenin gizlenmesini ve rahat yapılmasını sağlamıștır.

Türk basını, İtilaf kuvvetlerinin Çanakkale'den çekilmesini Türk milletinin asırlardan beri şevkle beklediği büyük bir zafer olarak duyurmuştur. İtilaf kuvvetlerinin Gelibolu'yu tamamen tahliye etmesinin duyulması tüm ülkeyi sevince boğmuş ve bu önemli zafer haberi tüm il ve ilçelerde coşkuyla kutlanmıştır. İstanbul'da bütün şehir, bayraklarla donatılmış ve sevinç gösterileri düzenlenmiştir. Türk basınında çıkan değerlendirmelerde Çanakkale Savaşı ile İtilaf Devletlerinin dünyadaki itibarının zedelendiği, savaşın İttifak Devletlerinin lehine döndüğ̈̈ ve Rusya'nın zor durumda kaldı̆̆ı dile getirilmiştir. Çanakkale harekâtı sonrası Türk ordusu diğer cephelerde daha rahat hareket etme imkânı yakalamıştır. İtilaf Devletlerinin Çanakkale Cephesi'nde başarısız olarak geri çekilmesi kamuoyunda savaşın gidişatını önemli ölçüde değiştireceği ve tüm dünyayı etkileyen siyasi, askerî ve sosyoekonomik sonuçlar doğuracağı gibi beklentiler ortaya çıkarmıştır.

Anahtar Kelimeler: Birinci Dünya Savaşı, Çanakkale Cephesi, Türk Basını, Çanakkale'nin Tahliyesi

Doç. Dr., Erciyes Üniversitesi Edebiyat Fakültesi, mucahitozcelik@hotmail.com 


\title{
Reflections of Allied Evacuation of the Gallipoli Peninsula on Turkish Press
}

\begin{abstract}
Turkish public kept abreast of all the latest developments about Gallipoli Front which was closely related with the fate of the First World War and Ottoman State. Having understood the impossibility of being successful at Gallipoli Front, British Army decided to evacuate the Peninsula.

Turkish troops could not notice the gradual British evacuation from Anzac Cove and Suvla Bay. Evacuation of Helles for British troops was more troublesome; leaving behind a significant amount of weapons, ammunition, food, clothing, medicine, means of transportation and communication they had to be content with the evacuation of their soldiers. Bombing Turkish areas by the warships continuously enabled British troops to hide the evacuation.

On Turkish Press, Allied evacuation of Gallipoli was announced as a great victory which Turkish nation had been waiting eagerly for centuries. Evacuation of Gallipoli news enraptured the whole country and all provinces and districts celebrated that important victory news enthusiastically. Turkish flags were waving in every part of Istanbul and demonstrations were held. In the evaluations of Turkish press it is expressed that besides ruining the reputation of Allies, Gallipoli War turned the course of the war to Central Powers' advantage. Moreover, Russia was stuck in a difficult situation with the Gallipoli victory. After Gallipoli War, Turkish troops caught the opportunity to move freely in the other fronts. Allied evacuation of Gallipoli with a failure led to such expectations in public that Gallipoli victory would change the course of the war and would cause some political, military and socio-economic results which could affect the whole word.
\end{abstract}

Keywords: The First World War, Gallipoli Front, Turkish Press, Evacuation of the Gallipoli Peninsula

\section{Giriş}

Birinci Dünya Savaşı’nda değişik cephelerde aynı anda savaşmak zorunda kalan Osmanlı Devleti için en önemli mücadeleler Çanakkale Cephesi'nde verilmiştir. Savaşın gidişatını değiştiren bu cephedeki deniz ve kara savaşları Türk kamuoyu tarafından yakından takip edilmiştir.

İtilaf Devletleri, Çanakkale saldırısı ile Almanların Varşova’yı almalarına mukabil İstanbul'u ele geçirerek bir taraftan Rusya'ya mühimmat diğer taraftan Rusya'dan memleketlerine gıda maddeleri sevk etmek istiyorlardı. ${ }^{1}$ Ayrıca Boğazları elde ettik-

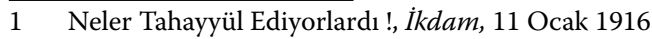


ten sonra Karadeniz'de hâkimiyet kurup başta Romanya ve Bulgaristan olmak üzere bütün Balkan hükümetlerini kendi kontrollerine alarak İttifak kuvvetlerini çembere almak istiyorlardı. ${ }^{2}$

Çanakkale Savaşları 19 Şubat 1915 tarihinde İtilaf filosunun Seddülbahir ve Kumkale istihkâmlarına taarruzuyla başlamıştır. Büyük İtilaf taarruzu ise on dokuz savaş gemisi ve birçok yardımcı gemi ile 18 Mart 1915'te yapılmıştır. Türk ordusunun müthiş savunmasını aşamayan İtilaf kuvvetlerinin bu teşebbüslerinde dört büyük gemisi batmış ve yedi gemisi de ağır hasar almıştır.

Boğazlardan geçilemeyeceğini anlayan İtilaf Devletleri 25 Nisan 1915’te Gelibolu yarımadasına ve Kumkale'ye asker çıkardıkları vakit karşılarında metin, kuvvetli, yılmaz bir Türk ordusu buldular. Arıburnu ve Seddülbahir'e çıan İtilaf kuvvetleri öncelikli olarak Kocaçimen Tepesi ve Alçıtepe'yi ele geçirmek istemişlerse de Türk ordusunun müthiş savunmasıyla geri çekilmek zorunda kalmışlardır. 1915 Nisan'ından Temmuz ayı sonuna kadar Arıburnu ve Seddülbahir'de sürekli taarruz yapan ve her seferinde geri püskürtülen İtilaf kuvvetleri 25 Temmuz'da Suvla Körfezi’ne 120 bin kişilik yeni bir kuvvet çıkardı. Ağustos ayında İngiliz ordusu Kocaçimen Tepesi’ni ele geçirmek için Anafartalar'da sürekli taarruz yapmışsa da mücadeleler İngilizlerin mağlubiyetiyle sonuçlanmıştır. ${ }^{3}$ Çanakkale Cephesi'nde yapılan bütün muharebelerin en kanlısı olan Anafartalar Savaşı'nda Albay Mustafa Kemal komutasındaki 7. ve 12. Tümenlerin İngiliz taarruzlarını durdurması, savaşın gidişatını etkilemiştir. ${ }^{4}$ İngiliz savaş muhabirleri ve askerî uzmanlara göre de Türk ordusu Anafartalar'da her zaman övünebileceği bir mücadele örneği göstermiştir. ${ }^{5}$

İtilaf kuvvetleri saldırılarını umutsuzca da olsa Ocak 1916 tarihine kadar devam ettirmiştir. Çanakkale Savaşı 19 Şubat 1915'ten 10 Ocak 1916 tarihine kadar yaklaşık 326 gün sürmüştür. İtilaf Devletleri kendi açıllamalarına göre; ölü, yaralı ve kayıp olmak üzere toplam 4.985 subay ve 204.690 er kaybetmişlerdir. Ayrıca 100.000 tonu geçen on iki savaş gemisi, altı denizaltı ve birçok yardımcı gemi kaybetmişlerdir. ${ }^{6}$

İtilaf Devletleri'nin Çanakkale Cephesi’nde başarısız olarak geri çekilmesi savaşın gidişatını önemli ölçüde değiştirdiği gibi tüm dünyayı etkileyen siyasi, askerî ve sosyoekonomik sonuçlar da ortaya çıkarmıştır. ${ }^{7}$

\footnotetext{
2 Yunus Nadi, Azim ve İmanın Zaferi, Tasvir-i Efkâr, 22 Aralık 1915

3 Birinci Dünya Savaşı Çanakkale Cephesi Harekâtı, Genelkurmay Basımevi, Ankara, 2014, s. 177-180

4 Joseph Pomiankowski, Osmanlı Imparatorluğunun Çöküşü, İstanbul, Kayıhan Yayınları 2003, s.121122.

5 İngilizler Anafartalar'da ve Arıburnu'nda Denize Döküldüler, Tasvir-i Efkâr, 21 Aralı 1915

6 Gelibolu Şebihceziresi Tamamen Tathir Edildi, Tasvir-i Efkâr, 10 Ocak 1916

7 Genelkurmay Başkanlığı, Birinci Dünya Harbinde Türk Harbi, c. V, 1. Kitap, Ankara, Genelkurmay Basımevi, s. 281-289.
} 


\section{1. İngilizlerin Anafartalar ve Arıburnu'ndan Çekilmesinin Yankıları}

İtilaf Devletlerinin Çanakkale'nin yalçın kayaları üzerinde bu kadar ısrar ederek Boğazları zorlamaktan bir türlü vazgeçmemeleri çok normaldi. Çünkü Çanakkale İtilaf Devletleri'ni kesin zafere götürecek en kısa ve en kolay yol gibi görünüyordu. Fakat deniz ve kara savaşlarıyla bunun sanıldığ 1 kadar kolay olmadığını anladılarsa da kendi ülkelerinde ve dünyada itibarlarının sarsılmaması için aylardır Çanakkale'yi geçme noktasında israrcı oluyorlardı. Ancak Türk ordusunun Almanlardan askerî teçhizat yardımı almaksızın bu derece savunma yapabileceklerini hesap edememişlerdi. ${ }^{8}$

İngilizler Kasım 1915'ten itibaren Almanya-Osmanlı bağlantısının sağlanması ile Çanakkale'ye yapılacak silah ve malzeme desteğinin Türk savunma hatlarını daha da güçlendireceğini bildiğinden Gelibolu yarımadasını almak için uğraşmanın anlamsız olduğunu düşünmeye başlamıștı. Bunun sonucunda İngiliz Genelkurmayı 7 Kasım 1915'te Çanakkale'yi boşaltma kararı aldı. ${ }^{9}$

İngilizlerin tahliye hazırlıklarına dair Türk keşif kolları ve dinleme postaları herhangi bir bilgi edinememiştir. İngilizler on günlük ve üç aşamalı bir çekilme planı hazırlamışlardır. Anafartalar ve Arıburnu cephesinde topçu atışlarına devam ederken bir yandan da geceleri teknelerle tahliye işlemini Türk tarafına hissettirmeden 20 Aralık 1915 sabahına kadar tamamlamışlardır. ${ }^{10}$ Çekilme hazırlıklarının Türk tarafına hissettirilmeden yapıldığını Enver Paşa Mecliste yaptığı konuşmasında kabul ediyordu. ${ }^{11}$ Liman Von Sanders Paşa'da hatıralarında İngilizlerin bu gizli tahliye işlemini doğrulamaktaydı.

21 Aralık 1915 tarihinde Türk Karargâh-1 Umumisinin, gazetelerde yayımlanan: "Çanakkale Cephesi'nde 19 Aralık gecesi ve 20 Aralık sabahı Anafartalar'da ve Arıburnu'nda düşman mevzilerine karşı şiddetli topçu ateşlerimiz ile başlayan taarruz hazırlığını önlemek için düşmanın öğleden sonra Seddülbahir'de bütün kuvvetiyle yaptığı taarruzun başarısız olmasıyla kuzeyde sürekli artan taarruzumuzdan kurtulamayacağını anlayan düşman kuvvetinin bir kısmını 20-21Arlık gecesi pek telaşla vapurlara bindirmeye başlamış ve bu hareket ortalığı uzun müddet istila eden kesif sise rağmen kıtaatımızın takibinden kurtulamamıştır. Bugün son alınan raporda Anafartalar'da ve Arıburnu'nda artık hiçbir düşman neferi bırakılmadığı ve bu mıntıkalarda kıtaatımızın kâmilen sahile kadar ilerleyerek düşmandan birçok ganimet, cephane, çadır ve top elde eylediği ve düşmanın bir deniz tayyaresi ateşlerimizle denize düşürülerek pilot ve rasidinin esir alındığı" șeklindeki tebliğ aslında Türkler adına Çanakkale zaferini duyurmaktayd..$^{12}$

8 Zaferin İtmamı, Tasvir-i Efkâr,10 Ocak 1916, Siyasiyat

9 Yusuf Hikmet Bayur, Türk Inkılâp Tarihi, Cilt:3, Kısım: I, Ankara, 1991, s. 385-386

10 Birinci Dünya Savaşı Çanakkale Cephesi Harekâtt, Genelkurmay Basımevi, Ankara, 2014, s. 222-223

11 Meclis-i Millimizde Şanlı Bir Gün, İkdam, 11 Ocak 1916

12 Tebliğ-i Resmî, Sabah, 22 Aralık 1915 
$\mathrm{Bu}$ resmî tebliğde İngilizlerin Arıburnu ve Anafartalar'dan çekilmeyi gizlemek için Seddülbahir'de şiddetli bir taarruza başladığı ve Türk tarafınca da İtilaf kuvvetlerinin çekilme harekâtının anlaşılmadığı görülmektedir.

İngilizler daha fazla ısrarın kendileri için daha vahim sonuçlar doğuracağını gördükleri için Çanakkale Cephesi'ni bir daha gelmemek üzere terk ve tahliye ediyordu. Tahliye sırasında önemli miktarda silah ve malzeme bırakmaları ise firar ediyor yorumlarına neden olmuştu. ${ }^{13}$

Tasvir-i Efkâr gazetesinde çıkan bir haberde, "Ingiliz ve Fransızların otuz sekiz santimlik topları ve savurdukları yüz binlerce mermileri; vatan için memleketin dört köşesinden koşup gelen İslam mücahidi Mehmetçik’in iman dolu sinesi karşısında çaresiz kaldı." ifadeleri kamuoyunun heyecanını gösteriyordu. ${ }^{14}$

İngilizlerin çekildiği bölgelerde Türk ordusunun ele geçirdiği ganimetler basına

"bir kolorduyu günlerce idare edecek muhtelif cinste erzak ve bir milyonu mütecaviz kum torbası, bin civarında çadır, 1.500 battaniye, 400 hasta tezkeresi, bin sandlk konserve, elli varil benzin, bir obüs topuyla yere gömülmüş birçok obüs mermisi, önemli miktarda tüfek ve cephane ile değişik teçhizat, üç yüz kilometre telefon teli, 180 kilometre mevani-i feriye teli"

şeklinde yansımıștır. ${ }^{15}$

Anafartalar ve Arıburnu'nun İtilaf kuvvetlerince tahliye edildiğinin duyulması tüm ülkeyi sevince boğmuş ve bu önemli zafer haberi tüm il ve ilçelerde coşkuyla kutlanmıştır. Başta İstanbul, Edirne, Adana, Eskişehir, Tarsus, İzmir, Trabzon, İnegöl, Akçaabat, Muğla, Samsun, Sivas, Burdur ve Bolu gibi yerler olmak üzere tüm yurtta sevinçle karşılanmış, şenlikler düzenlemiş ve şehirler bayraklarla donatılmıştır. Mektep ve medrese öğrencileri akşam fener alayları düzenlenmiş, millî marşlar söylenmiş, Başkumandan Vekili Enver Paşa'ya tebrik ve teşekkür telgrafları çekilmiştir. ${ }^{16}$ Birçok ilde şehit çocukları için yardım parası toplanmıştır. ${ }^{17}$ Ayrıca bu gibi muvaffakiyetlerin devamı için camilerde dualar edilmiştir. ${ }^{18}$ Yapılan konuşmalarda ise yakında "Mısır'ın ve Kafkasya'nın fethi” haberinin sevincini yaşama ümitleri dile getirilmiştir. ${ }^{19}$

Türk basını, İtilaf kuvvetlerinin Anafartalar ve Arıburnu'ndan çekilmesini büyük zafer olarak duyurmuş ve Türk milletinin asırlardan beri şevkle beklediği büyük bir

13 Düşmanın Münhezimen Terk ve Tahliye Ettiği Anafartalar, Tasvir-i Efkâr, 22 Ocak 1915

14 Düşmanın Münhezimen Terk ve Tahliye Ettiği Anafartalar, Tasvir-i Efkâr, 22 Ocak 1915

15 Tebliğ-i Resmî, İkdam, 23 Aralık 1915

16 Çanakkale Muzafferiyeti ve Vilayatta Sürur, Tercüman-ı Hakikat, 22 Aralık 1915

17 Taşrada Tezahürat, Tercüman-ı Hakikat, 23 Aralık 1915

18 Çanakkale Muzafferiyeti ve Vilayatta Sürur, Tercüman-ı Hakikat, 25 Aralık 1915

19 Çanakkale Muzafferiyeti ve Vilayatta Sürur, Tercüman-ı Hakikat, 24 Aralık 1915 
zafer kazandığını açıklamıştır. Çanakkale muzafferiyeti, harbin gidişatına etki edecek büyük hadiselere bir başlangıç olarak görülmüștür. ${ }^{20}$ İngilizlerin Anafartalar'da ve Arıburnu'nda uğradıkları bu felaket tüm dünyada çok büyük tesir bırakacak ve bütün Asya ve Afrika'nın artık gözleri açılacaktı. ${ }^{21}$ İngiliz ve Fransızların özellikle Müslüman sömürgelerinde sıkıntıya gireceği düşünülmekteydi. ${ }^{22}$

İngiltere ve Fransa Çanakkale seferine giriştiklerinde Türklerin yiğitliğini hesaba katmamışlardı. Türklerin yiğitlik ve fedakârlığı daha başlangıçtan itibaren İtilaf kuvvetlerinin bütün planlarını ve emellerini altüst etti. ${ }^{23}$

Osmanlı ajansının Çanakkale Zaferi’ni, Türk askerlerinin deniz kıyısında abdest almakta oldukları müjdesini vererek duyurması üzerine ${ }^{24}$ bu haber İslam askerlerinin dokuz aydır dünyanın en büyük iki düşmanına karşı Çanakkale Boğazı’nı müdafaa ve muhafazada gösterdikleri fedakârlığın sırrının izahı olarak değerlendirilmiştir. ${ }^{25}$

Çanakkale Zaferine inanamayan Türk basını, "kendimizi rüyada gibi hissediyoruz" diyerek tarifi mümkün olmayan bu sevinci ancak Fatihlerin, Yavuzların, Süleymanların devrinde yaşayan şanslı kişilerin anlayabileceğini düşünmekteydi. Bu zafer çağ başlangıcı olarak kabul edilebilirdi. Çünkü Çanakkale Savaşı ile İtilaf Devletlerinin dünyadaki itibarı zedelenmiş, savaş İttifak Devletlerinin lehine dönmüş ve Rusya'nın daha da kuvvetlenmesi önlenmişti. ${ }^{26}$

İngiliz ordusunun Anafartalar ve Arıburnu'ndan çekilmek zorunda kalması bütün İngilizler üzerinde derin etki yapmış ve bu karar Mecliste hükümete sert eleştirilerin yöneltilmesine neden olmuştur. ${ }^{27}$ Avam Kamarası üyeleri Çanakkale meselesinden dolayı hükümeti ağır bir şekilde eleştirmekte ve müsebbiplerinin cezalandırılmasını bile talep etmekteydi. ${ }^{28}$ Çanakkale yenilgisi kendi kamuoyunu aldatan İngiliz hükümetine karşı eleştirileri ve muhalefeti artırdı. ${ }^{29}$ İngiltere hükümeti Mısır'a sevk etmek için Çanakkale'deki kuvvetlerinin bir kısmını çekmek mecburiyetinde bulunduğunu açıklamışsa da buna İngilizler bile inanmamıştır. ${ }^{30}$

Ağaoğlu Ahmet'e göre, Çanakkale mücadelesini büyük ümitlerle başlatan ve orduydu Gelibolu'dan çekmek zorunda kalan İngiliz hükümeti Arıburnu'ndan kaçıp

20 Büyük Zafer, Tercüman-ı Hakikat, 21Aralık 1915

21 Ağaoğlu Ahmet, Türkün Bayramı, Tercüman-ı Hakikat, 21 Aralık 1915

22 Büyük Zafer Karşısında, İkdam, 11 Ocak 1916

23 Haza Min Fazli Rabbina, Sabah, 22 Aralık 1915

24 Ağaoğlu Ahmet, Türkün Bayramı, Tercüman-ı Hakikat, 21 Aralık 1915

25 Düşmanın Münhezimen Terk ve Tahliye Ettiği Anafartalar, Tasvir-i Efkâr, 22 Aralık 1915

26 Büyük Zafer Karşısında, İkdam, 11 Ocak 1916

27 Ağaoğlu Ahmet, Muvaffakiyet-i Harbiye, Tercüman-ı Hakikat, 25 Aralık 1915

28 Naçar Kalanların Kafilesi!, Tasvir-i Efkar 25 Aralık 1915

29 Siyasiyat, Söz ve İcraat, Tercüman-ı Hakikat, 24 Aralık 1915 (isimsiz makale)

30 Siyasiyat, Söz ve İcraat, Tercüman-ı Hakikat, 24 Aralık 1915 (isimsiz makale) 
gitmeyi muvaffakiyet gibi gösterse de bu tahliye İngiliz tarihini ebediyen lekeleyecekti ve Türk tarihine azim bir şan ve şeref katacak bir hadise olacaktı. ${ }^{31}$

$\mathrm{Bu}$ çekilme, İngilizlerin Çanakkale seferini başaramayacaklarını bilfiil ispat ve ilan etmeleri anlamına geliyordu. Anafartalar'da Gelibolu yarımadasına hâkim olan en yüksek tepeyi almak için altmış binden fazla İngiliz askerinin öldüğü düşünülürse çekilmenin başarısızlığın kabulü anlamına geldiği anlaşılırdı. Bundan sonra Gelibolu sahillerinde her hangi bir noktaya bir daha asker çıkarılması ise imkânsız görülüyordu. ${ }^{32}$

Çanakkale'den çekilen İngiliz askerinin Selanik'e gönderileceği söylense de Misır kıtasına gönderilmesi pek muhtemeldi. Çünkü İngilizler için asıl büyük tehlike Selanik ve Garp Cephesinden ziyade Mısır'da oluşabilirdi. Esasen Çanakkale seferi iddia edildiği gibi sadece Rusya'nın teşviki ile olan bir İngiliz teşebbüsü değildi. Bu sefer bilhassa Türk ordusunun Misır'a hücumunu erteletmeye yönelik bir teşebbüstü. ${ }^{33}$

İngiltere ve Fransa, Anafartalar ve Arıburnu'nda uğradıkları felaketi ve Türk ordusunun başarısını örtmeye çalışıyorlardı. Fakat hiçbir İngiliz ve Fransız, kendi isteğiyle bu yerlerden çekilmiş olduğuna inanmazdı ve inanmayacaktı. Fransa Millî Meclisindeki muhaliflerin evvelce Çanakkale seferinde Rusya'nın olduğu gibi bu defa da Sırpların imdadına yetişmek üzere hazırlandığına ve bunda da muvaffak olacağına dair çıkarılan rivayetlere inanmak için insanın ahmak olması gerektiği yönündeydi. ${ }^{34}$

Kamuoyunda, İngiltere'nin Çanakkale hezimetini unutturmak için ortaya attığı Selanik seferinin de Çanakkale gibi hezimetle biteceği düşüncesi vardı. ${ }^{35}$ Gerek Çanakkale'de ve gerekse Balkanlarda Türk ve Bulgar darbelerine hedef olan İtilafçıların Yakındoğu için yaptıkları planlardan da vazgeçtikleri yakın bir zamanda görülecekti. $^{36}$

Arıburnu-Anafartalar cephesinden firar eden İtilaf kuvvetleri Çanakkale'deki hezimetlerini fiilen itiraf ve ilan etmişlerdi. İngilizler ve Fransızların denizden olduğu gibi karadan da Boğazı ele geçiremeyecekleri artık kesin olarak anlaşılmıştı. İngiltere ve Fransa'nın bu çekilişi aslında çok önceden belli olan Türk zaferinin onayı anlamına geliyordu. ${ }^{37}$ Artık İtilafların Seddülbahir'den de atılmaları çok yakındı.

Boğazlar şu cihan harbinin âdeta sıklet merkezini teşkil etti. Hakikaten Çanakkale müdafaasında Türk ordusunun sınırlı silah ve mühimmat imkânlarına rağmen

31 Ağaoğlu Ahmet, Muvaffakiyet-i Harbiye, Tercüman-ı Hakikat, 25 Aralık 1915

32 Vakayı Harbiye, Tercüman-ı Hakikat,24 Aralık 1915 
gösterdiği vatanseverlik örneği cihan tarihinde önemli etkiler yapacak ve ihtimal ki İstanbul'un fethi gibi yeni bir devrin başlangıcı ve sebebi sayılacaktı. Bundan dolayı bu kanlı müdafaa ve mukavemetin Dünya Savaşı'nda Almanlara temin ettiği faydaları herkesten iyi gören Alman yetkililerin ve Alman kamuoyunun memnuniyet ve takdirlerini ifade etmeleri bunun en iyi göstergesiydi. ${ }^{38}$

Anafartalar Cephesi'nden gerçekleşen tahliyeler sonrasında "söz konusu askerlerin sayısının kaç olduğu, nereye götürülecekleri ve Seddülbahir'den çekilip çekilmeyecekleri" tartışmaları gündeme geldi. ${ }^{39}$ İngiliz ve Fransızların yakın bir zamanda Seddülbahir'i de terk ve tahliyeye teşebbüs edecekleri söylenebilirdi. Çünkü İngiliz ve Fransızların Seddülbahir'de tutundukları yerler hakikaten pek dar olup 6-7 kilometreyi geçmeyen bir sahadan ibaretti. Bu sahada Türk topçusunun saldırılarına karşı uzun süre savunma yapmak imkânsızdı. ${ }^{40}$

\section{2. İngilizlerin Çanakkale’den Tamamen Çekilmesinin Türk Basınına Yansiması}

Ocak 1916'da yaklaşık olarak bir yıldır devam eden Çanakkale Savaşları için artık yolun sonuna gelinmişti. İtilaf Devletleri'nin daha önce Anafartalar ve Arıburnu'ndan çekilmeye mecbur bırakılmaları Seddülbahir'deki çatışmaları şiddetlendirmişti. Aslında İtilaf Devletleri Seddülbahir'den de çekilmeye karar vermişti fakat bunu gizleyebilmek amacıyla bombardımanı hızlandırmıştı. Bu durumla ilgili basındaki bir haberde, "İngiliz ve Fransızlar galiba Anafartalar ve Arıburnu'ndan ricat ve firara mecbur olmalarından mütevellit yeis ve infiallerinin acısını Seddülbahir'de lüzumlu-lüzumsuz faaliyet göstermekle almak istiyorlar." ifadeleri İngilizlerin çekilme harekâtını gayet iyi bir şekilde gizlediklerini göstermekteydi.

Bununla birlikte basın, İtilaf Devletlerinin Balkanlarda girişeceği bir askerî hareket öncesinde Selanik'e askerî yığınak yaptıkları bir sırada Çanakkale'de önemli bir harekâtta bulunmalarını imkân dışı görüyordu. Bundan dolayı İngiliz ve Fransızların muhtemelen Sedülbahir'de de tahliyeye hazırlandıkları ve bunu gizlemek için Türk cephelerini sürekli bombardıman altında tuttuklarını düşünüyordu. Türk kamuoyunda -İngiliz ve Fransızlar kendileri çekilmezse- Türk ordusunun kısa sürede Çanakkale bölgesini düşman askerlerinden temizleyeceğine inanç tamdı. ${ }^{41}$ Türk ordusu da Seddülbahir'de İngilizleri tahliyeye zorlamak için saldırılarına hız vermişti ve Türk uçakları İngiliz mevzilerini sürekli bombalamaktaydı. ${ }^{42}$

38 Acaba Nereye Gidiyorlar?, Tasvir-i Efkâr, 23 Aralık 1915

39 Acaba Nereye Gidiyorlar?, Tasvir-i Efkâr, 23 Aralı 1915

40 Naçar Kalanların Kafilesi!, Tasvir-i Efkâr, 25 Aralık 1915

41 Seddülbahir'de Kahır ve Tedmir Olunacaklar, Tasvir-i Efkâr, 2 Ocak 1916

42 Seddülbahir Şiddetli Ateș Altında, Tasvir-i Efkâr, 9 Ocak 1916 
Türk yetkililerde ocak ayı başlarında İtilaf Devletlerinin Boğazları geçme düşüncesinden vazgeçerek Çanakkale bölgesini boşaltacakları veya Türk ordusu tarafından gerçekleştirilecek taarruzla İtilaf kuvvetlerinin bölgeden çekilmeye zorlanacağı beklentisi vardı. Beklentiler gerçekleşmiş ve İngilizler ani bir kararla günlerdir gizledikleri tahliye işlemini 9 Ocak 1916 gecesi tamamlamışlar ve sekiz buçuk aylık müthiş ve kanlı muharebelerden sonra Seddülbahir bölgesini boşaltarak Gelibolu'dan tamamen çekilmişlerdir. ${ }^{43}$

İtilaf kuvvetleri Selanik ile meşgul oldukları bir dönemde Çanakkale'de kalamayacaklarını biliyorlardı. Berlin-İstanbul yolunun açılmasıyla birlikte Almanlardan uzun menzilli ve etkili topların gelmesiyle birlikte ${ }^{44}$ denize dökülecekleri bilen İngiliz ve Fransız kuvvetleri müthiş bir zamanlama ile Seddülbahir'den çekildiler.

Enver Paşa'nın Çanakkale Zaferi dolayısıyla Mecliste yaptığı konuşmasında, “Arıburnu'nda iki yüz elli bin kişilik bir kuvvetin bir gecede çekilmesi tabii tasavvur edilemez. İtilaf Devletlerinin çekilebileceğini biliyorduk ama hazırlıklarını hiç fark etmedik. Yalnız şimdi anlaşılıyor ki Kızılhaç gemilerini bu maksat için kullanmışlar.” itirafı oldukça manidardır. "Türk keşif kolları düşman siperlerine yirmi otuz adım mesafeye kadar sokulup İngiliz ve Fransızları taciz ettikleri hâlde İngilizler farkına varılmaksızın çekilmeye muvaffak oldukları için hakikaten ne kadar iftihar etseler yeri vardır." ifadesi de Enver Paşa'nın İngilizlerin başarılı bir çekilme geçekleştirdiklerini kabul etmesi anlamına gelmekteydi. Arıburnu ve Anafartalar'dan çekildikten sonra İngilizlerin Seddülbahir'de kalmasını imkânsız gören Enver Paşa, düşmanın çekileceğini bildiklerini ama ne vakit çekileceğini kesin olarak tahmin edemediklerini dile getirmiştir. ${ }^{45}$

İtilaf Kuvvetlerinin Gelibolu'yu tamamen tahliye etmesinin İstanbul'da duyulmasıyla beraber bütün şehir sancaklarla donatılmış ve sevinç gösterileri düzenlenmiştir. Mektep öğrencileri vatan şarkıları söyleyerek askerlerle birlikte caddeleri dolaşmışlardır. Çanakkale şehitlerinin çocuklarının kaldığı Darüleytam talebeleri de bu merasime iştirak etmiştir. Akşamüzeri Müdafaa-i Millîye, Donanma, Hilal-i Ahmer Cemiyetleri ile esnaf ve tüccar cemiyetleri, mektep talebeleri ve ahaliden binlerce kişinin katılımıyla teşekkül eden bir kafile; önünde bahriye mızıkası ve arkada davullar olduğu hâlde Nuruosmaniye, Çemberlitaş, Divanyolu yoluyla Harbiye Nezareti önüne gelmiş ve tezahüratta bulunmuştur. Aynı alay Harbiye Nezaretinden sonra Divanyolu, Alemdar Caddesi ve köprü yoluyla Beyoğlu'na gitmiștir. Alay Beyoğlu'nda müttefiklerin elçilikleri önüne giderek tezahüratta bulunduktan sonra geri dönmüş-

43 Siyasiyat, Zaferin İtmamı, Tasvir-i Efkâr, 10 Ocak 1916 (isimsiz makale)

44 Meclis-i Millîmizde Şanlı Bir Gün, İkdam, 11 Ocak 1916

45 Meclis-i Millîmizde Şanlı Bir Gün, İkdam, 11 Ocak 1916 
tür. Bu mutlu günde İstanbul'daki tüm okullar tatil edilmiştir. Cami minareleri ve yangın kuleleri kandillerle ışıklandırılmıştır. ${ }^{46}$

İtilaf Devletleri, bu savaşı kazanırsa ne kadar önemli kazançlar elde edip harbin gidişatını önemli oranda değiştireceklerini düşünüyorlarsa yenilgilerinin de İttifak Devletlerine önemli kazançlar sağlayacağının farkındaydılar. Bundan dolayı Türk ordusunun Çanakkale'deki başarılı savunması İttifak Grubunda harbin kazanılacağına olan inancı inanılmaz derecede artırdı. Bu zaferin, yalnız Osmanlı tarihinde değil, hiç şüphesiz dünya tarihinde de önemli değişimlere başlangıç teşkil edeceğinde herkes hemfikirdi. Türk kamuoyu bu büyük millî gururu sağlamak için sekiz buçuk aydır fedakârlığın, yiğitliğin ve vatanseverliğin en ulvi derecesini gösteren Türk ordusuna binlerce selam ve hürmetlerini sunmaktaydı. ${ }^{47}$ Çünkü Türk ordusu tüm imkânsızlıklarına rağmen yüzlerce, binlerce şehit verdi, kanlarını akıttı fakat düşman hücumları karşısında bir adım bile gerilemedi. Pay-i taht-ı saltanatın kapılarını, ecdadını memnun edecek bir azim ve metanetle müdafaa etti. ${ }^{48}$ Tarih bir gün ihtimal ki Çanakkale'ye 'fetih olunamaz kale' namını layık görecektir.

Daily Telegraph gazetesinin, İngiliz ordusunun Anafartalar'dan çekilmesi sonrasında Seddülbahir'de sürekli kalacağını ve burada yeni bir Cebelitarık oluşturarak Türk milletinin Akdeniz’e çıkışının engelleneceğini iddia ettiği bir sırada İngilizler Seddülbahir'i de boşaltmışlardır. ${ }^{49}$ İngiliz muhalifler ise hükümete "Madem önceden çekilme planlanıyordu niye binlerce askerin ölmesine sebep olundu?” şeklinde ifadelerle sert eleştiriler yöneltti. Daily Mail gazetesinde "Feci Bir Hamakatın Tarihçesi" başlığı ile çıkan bir yorumda ise halkın aylarca kandırıldığ 1 anlatılmaktaydı. ${ }^{50}$ İngiltere'de askerlik hizmetinin mecburi hale getirilmesinin İngilizlerin Gelibolu'dan çekildiği günlere rastlaması da manidar bulunmuştur. İtilaf Devletlerinin sekiz dokuz ay evvel pek büyük ümitlerle açtıkları bir davanın sonuçsuz kalması tabiatıyla cihan harbinde yeni bir safhaya başlangıç teşkil etmekteydi.

Dünyanın kara ve deniz gücü olarak en kuvvetli iki devleti, Akdeniz boğazında gırtlağına sarılarak boğmak istedikleri Türk ve Müslümanın yiğitliği önünde hiçbir şey yapamayarak pek çok zayiata katlanmaya ve nihayet sefil ve baş aşağı çekilip gitmeye mecbur oldular. ${ }^{51}$ Çanakkale müdafaasının kesin bir galibiyet ile sonuçlanması Rus ordusunu zor durumda bırakmış ve nihayet Bulgaristan'ın İttifak Devletleri hesabına kazanılmasını temin etmiştir. ${ }^{52}$ Çanakkale harekâtı sonrası Türk ordusu diğer

46 Gelibolu Şebihceziresi Tamamen Tathir Edildi, Tasvir-i Efkâr, 10 Ocak 1916

47 Siyasiyat, Zaferin İtmamı, Tasvir-i Efkâr, 10 Ocak 1916 (isimsiz makale)

48 Siyasiyat, Yeni Safha, Tasvir-i Efkâr, 11 Ocak 1916 (isimsiz makale)

49 Siyasiyat, Yeni Safha, Tasvir-i Efkâr, 11 Ocak 1916 (isimsiz makale)

50 Çanakkale Muvaffakiyeti ve Ecnebi Matbuatının Takdiratı, Tercüman-ı Hakikat, 25 Aralık 1915

51 Yunus Nadi, Cihan Harbinde Osmanlı Ordusu, Tasvir-i Efkâr, 14 Ocak 1916

52 Yunus Nadi, Azim ve İmanın Zaferi, Tasvir-i Efkâr, 22 Aralık 1915 
cephelerde daha rahat hareket etme imkânı yakalamıştır. ${ }^{53}$ Enver Paşa, Çanakkale muzafferiyetinden sonraki beyanatında, "düşmanlarımızı yalnız hudutlarımızın haricine çıkarmak değil, hatta evvelce gasp eyleyip pis ayaklarıla çiğnemekte oldukları arazimizi dahi istirdat eyleyeceğimiz" șeklindeki sözleri başkumandan vekilinin geleceğe nasıl emniyet ve metanetle baktığını açıkça göstermekteydi.

Türk ordusunun Çanakkale'de en az beş yüz bin kişilik düşman kuvvetini üzerine çekme ve onların taarruz ve hücumunu dokuz ay müddetle püskürtme hususunda gösterdiği yüksek gayreti, gerek Almanlar ve gerekse Avusturyalılar kendilerine sağladığı büyük menfaatlerden dolayı her firsatta minnet ve şükranla dile getiriyorlardı. Almanya imparatoru tarafından Osmanlı padişahına çekilen telgraf da bunun göstergesiydi. ${ }^{54}$

Meclis-i Ayan Reisi Rifat Bey, Çanakkale Zaferi münasebetiyle Meclis adına ordu kumandanlığına gönderdiği tebrik mesajında "Tarih-i âlemde ebedi bir sahife işgal edecek olan bu son harika-i hamasetin harikalar yetiștiren kahramanları isbat ettiler ki bir sal parçası üstünde Gelibolu'ya geçerek cihangirane bir devlet vücuda getiren Osmanlılar yine o noktada o devletin hayat-ı istiklalini müdafaa edecek kana maliktirler." şeklindeki sözleri ile Türk ordusuna olan inancını göstermekteydi. ${ }^{55}$

Arıburnu'nda İngiliz mevzilerinden Kocaçimen tepesine olan mesafe 1500 metre yani Ayasofya Aksaray arası kadardı. Ingilizler bu kadar mesafeyi sekiz ayda geçemediler, nihayet yenilerek çekilip gittiler. İngiliz ve Fransız ordularının müthiş imkânlara sahip olmasına rağmen, imkânları çok sınırlı olan Türk ordusuna mağlup olmaları İslam askerlerine ebedi bir şan ve şeref kazandırmıştır. Çanakkale müdafaası harb-i umumi üzerindeki etkisi açısından en önemli birkaç olaydan biriydi ${ }^{56}$ Çünkü Alman basını İngiltere'nin Gelibolu'dan atılması ile tüm dünyada nüfuz ve itibarını kaybettiğini ve bu mağlubiyetin aynı zamanda Müslüman sömürgelerde de kısa sürede hissedileceğini düşünmekteydi. ${ }^{57}$ Avusturya basını ise Fransızların ve İngilizlerin Gelibolu'dan kendi istekleri ile çekildikleri ve kuvvetlerini Selanik ve Mısır'a nakil ettikleri şeklindeki sahte beyanata inanan kimsenin olmayacağını yazmaktaydı. Avusturya Rayhistapost gazetesi ise Türklerin bu zaferle Fransız ve İngiltere'den ziyade Rusya'yı yendiklerini düşünmekteydi. ${ }^{58}$

Bulgar basınında kendi güvenlikleri açısından son derece önemli olan bu zafer karşısında Türk milletine övgüler yağdırılmıştı ve Gelibolu yarımadasının tahliye-

53 Meclis-i Millimizde Şanlı Bir Gün, İkdam, 11 Ocak 1916

54. Enver Paşa'nın Beyanatı, Tasvir-i Efkâr, 12 Ocak 1916

55 Seddülbahir Meșher-i Ganaim, Tasvir-i Efkâr, 12 Ocak 1916

56 Sekiz Ayda Ayasofya'dan Aksaray'a Gidememek Meselesi!, Tasvir-i Efkâr, 19 Şubat 1916

57 Gelibolu Muzafferiyeti Münasebeti İle, Sabah, 23 Aralık 1915

58 Müttefiklerimizin Takdiratı, Tercüman-ı Hakikat, 23 Aralık 1915 
sinin tüm Balkanların İtilaf kuvvetlerince boşaltılması neticesini doğuracağı ifade edilmekteydi. ${ }^{59}$

Fransız basını ise İstanbul-Berlin yolunun açılması üzerine Selanik'in önem kazanmasından dolayı İtilaf kuvvetlerinin Çanakkale'den çekildiğini yazarak yenilgiye kılıf bulmaya çalışmaktaydı. İtalya gazeteleri çekilmenin endişe verici olduğunu ve Rusya'da olumsuz gelişmelere neden olabileceğini öngörmekteydi. ${ }^{60}$ İngiliz muhalifler ise hükümete "madem önceden çekilme planlanıyordu niye binlerce askerin ölmesine sebep olundu" şeklinde ifadelerle sert eleştiriler yöneltti. Daily Mail gazetesinde "feci bir hamakatin tarihçesi" başlığı ile çıkan bir yorumda ise halkın aylarca kandırıldığı anlatılmaktaydı. İtilaf yanlısı Danimarka basını kara ve deniz savaşlarının aynı anda yapılmamasını İtilafların yenilme sebebi olarak gösteriyor ve ciddi can kaybına yol açan uzun süreli ısrarı da eleştiriyordu. ${ }^{61}$ Ayrıca İngiltere'nin Mısır'da artık rahat oturamayacağına dikkat çekiliyordu. ${ }^{62}$ İsviçre basını ise İngiltere'nin Şark'taki nüfuzunun büyük bir yara aldığının inkâr edilemeyeceğini düşünmekteydi. ${ }^{63}$

\section{Tahliye Sonrası Çanakkale'den İzlenimler ve Ele Geçen Ganimetler}

Osmanlı Genelkurmayı Türk milletinin kazandığı bu büyük zaferin ayrıntılarını görmesi ve moralinin yükselmesi amacıyla tahliye sonrası Gelibolu'ya gazetecileri götürmüștür.

Tasvir-i Efkâr gazetesi muhabiri İngilizlerin boşalttığı yerlerle ilgili "meşher-i ganaim" başlığı ile çıkan haberde ganimetlerin tür ve çeşidinin yazılmasının bile sayfalar süreceği dile getirmiştir. Haberin içeriği ise "Ele geçirilen patates, pirinç, un çuvalları uzaktan ufak tepeleri andırıyor. Depolar kullanılmamış çizme, potin, kaput, elbise ile doludur. Bugüne kadar birçok hastane otomobili ve motosiklet, binlerce edevat-1 istihkamiye, bomba mancınıkları, seyyar ameliyathaneler bulunmuştur. Bundan başka binden ziyade katır ve beygir vardır. Düşman bu zavallı hayvanları zehirlemekten çekinmemiştir. Amele kollarımız düşman ecsadını defin ede ede bitirememiştir. Taharri kollarımız ise sürekli ganaim topluyor. Buradaki ganaimin Arıburnu'ndakini fersah fersah geçtiği muhakkaktır. Düşman alelacele firarı esnasında un ve araba yığınlarını ateșe vermişse de askerimiz bu yangınları söndürerek erzakı kurtarmışlardır. Türk askerlerinin Kerevizdere'de düşman siperlerini bastığı vakit orada siper yollarının birine asılı büyük harflerle yazılı şu levhayı bulmuşlardır: 'İstanbul Caddesi' İtilaflar yüz binlerce kayıp verdiği hâlde uzaktan rüzgârını bile koklayamadığı İstanbul hakkında

59 Müttefiklerimizin Takdiratı, Tercüman-ı Hakikat, 23 Aralık 1915

60 Gelibolu Ricati Hakkında, Tasvir-i Efkâr, 25 Aralık 1915

61 Çanakkale Muvaffakiyeti ve Ecnebi Matbuatının Takdiratı, Tercüman-ı Hakikat, 25 Aralık 1915

62 Gelibolu Ricati Hakkında, Tasvir-i Efkâr, 25 Aralık 1915

63 Çanakkale Muvaffakiyeti ve Ecnebi Matbuatının Takdiratı, Tercüman-ı Hakikat, 25 Aralık 1915 
kurduğu hülyalara mukabil İstanbul'a karşı yürümeye çalışan düşmanın gideceği yol işte İngiliz ve Fransızların uğradıkları hüsran ve mağlubiyet yoludur." şeklindeydi. ${ }^{64}$

İngilizlerin çekildiği bölgelerde bulunan iskelelerde birçok sandık ve kutu ile önemli miktarda malzemenin varlığı hemen hiçbir şey tahrip etmeye vakit bulmaksızın çekilme işleminin yapıldığını gösteriyordu. Seddülbahir'de Zığındere taraflarında İngiliz subaylara ait olmak üzere kum torbalarından imal ve inşa edilen mükemmel barakalar vardı. Bu barakalar kum torbalarından yapılmışsa da pencere ve kapılarına varıncaya kadar düşünülerek yapıldığı görülmekteydi. Bu da İngilizlerin Seddülbahir'de müsaade edilmiş olsaydı pek uzun uzadıya kalmak niyetinde bulunduklarını gösteriyordu. Bu barakaların da olduğu gibi terk edilerek hiçbir suretle tahrip edilmemiş olması İngilizlerin düzenli bir şekilde hiçbir şey terk etmeksizin Çanakkale'den çekildikleri hakkındaki iddiaların da asılsız olduğunu göstermekteydi. Ayrıca terk ettikleri barakaların üzerindeki telgraf ve telefon direk ve telleri İngilizlerin en ince teferruata varıncaya kadar mükemmel teçhizata sahip oldukları hakkında fikir vermekte ve buna rağmen Çanakkale'de hiçbir şey yapamayarak çekilmeye mecbur kalmaları Türk askerinin mukavemet ve müdafaada gösterdiği fedakârlığı gözler önüne sermekteydi. ${ }^{65}$

Tanin gazetesi adına Gelibolu’yu gezen savaş muhabiri Cemil Hakkı, İngilizlerin çekildiği bölgeye yaptığı ziyaret sonrası izlenimlerini gazetesinde yazı dizisi olarak yayımlamıştır. İlk olarak Seddülbahir'de ve Tekeburnu civarında ganimet depolarını görmek için Kirte'ye gelen muhabirin ilk izlenimleri,

"Ingiliz siperlerinde yüzlerce İniliz askeri cesedi vardı. Ingilizler o kadar acele ile canlarını kurtarmak istemişler ki siperleri gerisinde bomba depolarını bile bir dakikada berhava etmek mümkün iken vakit bulamamışlar. Ingilizlere başlarındaki miğferler bile ağır gelmiş, bunları bile çıkarıp atmışlar. Bilhassa tüfek, kasatura yükünden büsbütün tecerrüt etmek istemişler. Cepheye giden umumi yolların kenarlarında tesadüf ettiğim her şey yerli yerindeydi. Her yerde ăgzina kadar dolu cephanelikler vardl. Ingilizler beygirler Türklerin eline geçmesin diye birçoğunu telef etmişlerdi ve bundan dolayı cephede müthiş bir koku vardı.” şeklindeydi. ${ }^{66}$

Aynı bölgede muhabirin gördükleri arasında, içi dolu hastane çadırları, eczanelerde serumlara varıncaya kadar kıymetli alet edevat, koltuk değnekleri, pamuk sandıkları, gaz sargıları, hastane matbahları, dezenfekte tulumbaları, gaz sobaları, portatif yataklar gibi bol miktarda sıhhiye malzemesi vardı. İngilizlerin sandıklar dolusu

64 Seddülbahir Meşher-i Ganâim, Tasvir-i Efkâr 12 Ocak 1916

65 Ne Bırakmışlar Neler Bırakmışlar?, Tasvir-i Efkâr, 17 Şubat 1916

66 Cemil Hakkı, Seddülbahir'de Ganimetlere Giderken, Tanin 29 Aralık 1916 
Kakao, süt ürünleri, bisküvi, kara üzüm, konserve, kavurma kutuları, çay, toz şeker gibi gıdalar bırakmışlardı. Muhabirin hesaplamasına göre 6075 adet peynir sandığı yani 303.750 kilo, 3213 reçel sandığı yani 874.200 reçel kutusu vardı.

Üçü tahrip edilmiş sekiz Kızılhaç otomobili haki boyalı yüzlerce motosiklet ve bisikletlerden hepsinin arka tekerlekleri üzerinde posta çantası koyma yerleri vardı. İngilizlerin gerek askerî haberleşmeyi gerekse posta mektuplarının dağıtımı konusunda oldukça itina gösterdikleri anlaşılıyordu. Mezarlıkları gayet düzenli ve tüm mezarların üzerinde yazı vardı. ${ }^{67}$

İngilizler çekildikten sonra da Seddülbahir'de boşalttıkları yerleri gemi ve uçaklarla bombalamaya devam ettiler. Buradaki depolarda pek çok cephane, tüfek, süngü, açılmamış fanila, don, gömlek balyaları, su geçmez muşambalar, elbise ve kaputlar, yeni postallar, su depoları ve binlerce çeşit demir eşya bırakmışlardı. Seddülbahir'de birakılanlar, Anafartalar'la kıyaslanamayacak kadar çoktu. ${ }^{68}$

Zı ğındere, İngilizler için doğal siperler olarak kullanılmıştı. Burada kurulan subay çadırları kitap, kirli iskambil kâğıtları ve içki ile doluydu. İngilizler her yere açtıkları kuyularla temiz ve dezenfekte edilmiş su kullanmışlardı. Siperlerdeki binlerce sandık bomba, tüfek, süngü, cephane teçhizat-ı seferiyeye müteallik ne varsa bırakıp kaçmışlardı. Telefon tertibatına da son derece ehemmiyet vermişler; ileri hatlar gerisindeki telefon santrallerinde belki elliye yakın telefon kablosuna tesadüf ettim. ${ }^{69}$

Tekeburnunda bulunan ordugâhta yeraltı hücrelerinde çamaşır yıkamaya mahsus makineler, askerlere verilen mükemmel dikiş torbaları vardı. Buruna biraz daha yakın bir mevkide yirmi kadar ekmek fırını vardı. Seddülbahir cihetinde atölyelerde demircilik aletleri, tel kafesler, tel örgü makinaları, kazma, kürek, baltalar, fıçılar dolusu muhtelif büyüklükte çiviler, makine yağları vardı. Teke koyunda İngilizler tarafından oluşturulmuş limanda küçük motorlu kayıklar ve yüzlerce cephane arabasının çoğu tahribe vakit bulamadan bırakılmıştı. İngilizler, büyük ordugâhlarını ve bilhassa büyük komutanların çadırlarını Kızılhaç işareti bulunan yerlerin yanına kurmuşlardı. Bu da gösteriyor ki İngilizler Türklerin pek medeni olduğunu, Kızılhaç işaretini gösteren mevkii bombalamayacağ 1 tahmin ediyorlardı. ${ }^{70}$

Cemil Hakkı, Ertuğrul koyundaki izlenimlerinde ise, “ Burada İngilizlerin yakmak için getirdikleri odun kütükleri vardı. Bu odun istifi herhalde bir orduyu bir sene idare edebilirdi. Yine Tekeburnu istikametinde yığınlar şeklinde patates, un, arpa, yulaf çuvalları istifleri arasında, âdeta bir şehrin yüksek binalı sokaklarında dolaşıyor gibiydik. Zavallı İngilizler bu yığınlardan bir ikisinin altından lağımlar açmışlar fakat patlatamaya vakit bulamadan kaçmışlar." şeklinde anlatıyordu. ${ }^{71}$

67 Cemil Hakkı, Seddülbahir'de Yarım Kalan Tahmin, Tanin, 7 Ocak 1916

68 Cemil Hakkı, Seddülbahir'de-2 Yarım Kalan Tahmin, Tanin, 8 Ocak 1916

69 Cemil Hakkı Seddülbahir'de Zığındere'de, Tanin 14 Ocak 1916

70 Cemil Hakkı Seddülbahir'de Tekeburnu Depoları, Tanin, 16 Ocak 1916

71 Cemil Hakkı, Ertuğrulkoyu ve Seddülbahir Tanin, 22 Ocak 1916 


\section{Sonuç}

Türk kamuoyu Birinci Dünya Savaşı'nda Osmanlı Devleti’nin kaderini yakından ilgilendiren Çanakkale Cephesi'yle ilgili gelişmeleri anbean takip etmiştir. Kasım 1915’ten itibaren Almanya-Osmanlı ulaşım bağlantısının sağlanmasıyla birlikte Türk savunma hatları daha da güçleneceği için İngilizler ısrarın kendilerine vahim sonuçlar doğuracağını görmüşler ve Çanakkale Cephesi'ni tahliye etmeye karar vermişlerdir.

Türk ordusu İngilizlerin on günlük bir sürece yayarak gerçekleștirdikleri Arıburnu ve Anafartalar'dan çekilme harekâtını fark edememiştir. Dönemin komutanlarının beyanatları da bunu doğrulamaktadır. Tahliye işleminin Türk ordusu tarafından fark edilmemesi İngilizlerin asker zayiatını en aza indirmiş ve önemli miktarda malzeme, cephane ve silah tahliye etmesine olanak sağlamıştır. Türk tarafının, Seddülbahir'in de tahliye edileceğini düşünmesi İngilizleri bu bölgede sıkıntıya sokmuş, öncekine göre daha zor bir tahliye gerçekleştirmelerine neden olmuştur. İngilizlerin savaş gemileriyle sürekli Türk bölgelerini bombalaması tahliyenin gizlenmesini ve daha rahat yapılmasını sağlamıştır. İtilaf kuvvetleri 9 Ocak 1916 gecesi tahliye işlemi tamamlamış ve sekiz buçuk aylık müthiş ve kanlı muharebelerden sonra Seddülbahir bölgesini boşaltarak Gelibolu'dan tamamen çekilmişlerdir.

Türk basını, İtilaf kuvvetlerinin Anafartalar ve Arıburnu'ndan çekilmesini Türk milletinin asırlardan beri şevkle beklediği büyük bir zafer olarak duyurmuştur. Çanakkale Savaşı ile İtilaf Devletlerinin dünyadaki itibarı zedelenmiş, savaş İttifak Devletlerinin lehine dönmüş ve Rusya'nın daha da kuvvetlenmesi önlenmiştir. Çanakkale muzafferiyeti, harbin gidişatına etki edecek büyük olaylara bir başlangıç olarak görülmüş̧ür. İngilizlerin Gelibolu'da uğradıkları bu yenilginin ardından Müslüman sömürgelerinde sıkıntıya gireceği düşünülmekteydi. Bu tahliye İngiliz tarihini ebediyen lekeleyecek ve Türk tarihine azim bir şan ve şeref katacak bir hadiseydi.

İtilaf Kuvvetlerinin Gelibolu'yu tamamen tahliye etmesinin duyulması Türkiye'yi sevince boğmuş ve bu önemli zafer haberi tüm il ve ilçelerde coşkuyla kutlanmıştır. İstanbul'un her yeri sancaklarla donatılmış ve sevinç gösterileri düzenlenmiştir. Türk basınına yansıdığı şekliyle Çanakkale Zaferi'nin Avrupa kamuoyunda da geniş yer bulduğu anlaşılmaktadır. İngiliz ve Fransız basınında tahliyeyi haklı çıkaracak bahaneler üretilmiştir. Alman, Bulgar ve Avusturya basını ise Çanakkale zaferinin kendileri için de ne anlama geldiğini bildikleri için Türk ordusundan övgüyle bahsetmişlerdir. Tarafsız ülke basını ise kara ve deniz savaşlarının aynı anda yapılmamasını İtilafların yenilme sebebi olarak gösteriyor ve ciddi can kaybına yol açan uzun süreli ısrarı da eleştiriyordu. Ayrıca İngiltere'nin Mısır'da artık rahat oturamayacağına dikkat çekiliyordu.

İngilizlerin öncelikli olarak askerlerini güvenli bir şekilde tahliye etmeyi amaçladığını ve bunda da muvaffak olduğunu söyleyebiliriz. İngilizlerin Çanakkale’den 
çekilme işlemi sırasında geride önemli miktarda silah, cephane, gıda maddesi, giyim eşyası, ilaç, ulaşım ve haberleşme araçları bırakması çekilmenin ani ve hızlı olduğunu göstermektedir.

Türk kamuoyu, İtilaf Devletlerinin Çanakkale Cephesi’nde başarısız olarak geri çekilmesini savaşın gidişatını önemli ölçüde değiştirecek önemli bir olay olarak görmüş ve bundan dolayı İngilizlerin zayiat vermeden çekilmesinden ziyade Çanakkale Cephesi'nde başarılı olamadıklarını kabullenip Gelibolu'dan çekilmeleri üzerinde durulmuştur. 


\section{KAYNAKÇA}

Acaba Nereye Gidiyorlar?, Tasvir-i Efkâr, 23 Aralık 1915

Ağaoğlu Ahmet, Muvaffakiyet-İ Harbiye, Tercüman-ı Hakikat, 25 Aralık 1915

Ağaoğlu Ahmet, Türkün Bayramı, Tercüman-ı Hakikat, 21 Aralık 1915

Birinci Dünya Savaşı Çanakkale Cephesi Harekâtı, Genelkurmay Basımevi, Ankara, 2014, s. 177-180

Büyük Zafer Karşısında, İkdam, 11 Ocak 1916

Büyük Zafer, Tercüman-ı Hakikat, 21Aralık 1915

Cemil Hakkı Seddülbahir'de Tekeburnu Depoları, Tanin, 16 Ocak 1916

Cemil Hakkı Seddülbahir'de Zığındere'de, Tanin 14 Ocak 1916

Cemil Hakkı, Ertuğrulkoyu ve Seddülbahir Tanin, 22 Ocak 1916

Cemil Hakkı, Seddülbahir'de Ganimetlere Giderken, Tanin 29 Aralık 1916

Cemil Hakkı, Seddülbahir'de Yarım Kalan Tahmin, Tanin, 7 Ocak 1916

Cemil Hakkı, Seddülbahir'de-2 Yarım Kalan Tahmin, Tanin, 8 Ocak 1916

Çanakkale Muvaffakiyeti ve Ecnebi Matbuatının Takdiratı, Tercüman-ı Hakikat, 25 Aralık 1915

Çanakkale Muzafferiyeti ve Vilayatta Sürur, Tercüman-ı Hakikat, 22 Aralık 1915

Çanakkale Muzafferiyeti ve Vilayatta Sürur, Tercüman-ı Hakikat, 25 Aralık 1915

Çanakkale Muzafferiyeti ve Vilayatta Sürur, Tercüman-ı Hakikat, 24 Aralık 1915

Düşmanın Münhezimen Terk ve Tahliye Ettiği Anafartalar, Tasvir-i Efkâr, 22 Aralık 1915

Düşmanlarımızın Zelilane Tevli, İkdam, 23 Aralık 1915, (isimsiz makale)

Enver Paşa'nın Beyanatı, Tasvir-İ Efkâr, 12 Ocak 1916

Gelibolu Muzafferiyeti Münasebeti İle, Sabah, 23 Aralık 1915

Gelibolu Ricati Hakkında, Tasvir-i Efkâr, 25 Aralık 1915

Gelibolu Şebihceziresi Tamamen Tathir Edildi, Tasvir-İ Efkâr, 10 Ocak 1916

Genelkurmay Başkanlığı, Birinci Dünya Harbinde Türk Harbi, C.V, 1. Kitap, Ankara, Genelkurmay Basımevi, s.281-289.

Haza Min Fazli Rabbina, Sabah, 22 Aralık 1915

İngilizler Anafartalar'da ve Arıburnu'nda Denize Döküldüler, Tasvir-i Efkâr, 21 Aralık 1915

Joseph Pomiankowski, Osmanlı İmparatorluğunun Çöküşü, İstanbul, Kayıhan Yayınları 2003, s.121-122.

Meclis-i Millîmizde Şanlı Bir Gün, İkdam, 11 Ocak 1916

Müttefiklerimizin Takdiratı, Tercüman-ı Hakikat, 23 Aralık 1915

Naçar Kalanların Kafilesi!, Tasvir-i Efkâr, 25 Aralık 1915

Ne Bırakmışlar Neler Bırakmışlar?, Tasvir-i Efkâr, 17 Şubat 1916 
Neler Tahayyül Ediyorlardı !, İkdam, 11 Ocak 1916

Seddülbahir Meşher-i Ganaim, Tasvir-i Efkâr, 12 Ocak 1916, Başlık Yanlış

Seddülbahir Şiddetli Ateş Altında, Tasvir-i Efkâr, 9 Ocak 1916

Seddülbahir'de Kahır ve Tedmir Olunacaklar, Tasvir-i Efkâr, 2 Ocak 1916

Sekiz Ayda Ayasofya'dan Aksaray’a Gidememek Meselesi!, Tasvir-İ Efkâr, 19 Şubat 1916

Söz ve İcraat, Tercüman-ı Hakikat, 24 Aralık 1915 (isimsiz makale)

Taşrada Tezahürat, Tercüman-ı Hakikat, 23 Aralık 1915

Tebliğ-i Resmî, İkdam, 23 Aralık 1915

Tebliğ-i Resmî, Sabah, 22 Aralık 1915

Vakayı Harbiye, Tercüman-ı Hakikat,24 Aralık 1915 siyasiyat

Yeni Safha, Tasvir-i Efkâr, 11 Ocak 1916 (isimsiz makale)

Yunus Nadi, Azim ve İmanın Zaferi, Tasvir-i Efkâr, 22 Aralık 1915

Yunus Nadi, Cihan Harbinde Osmanlı Ordusu, Tasvir-İ Efkâr, 14 Ocak 1916

Yusuf Hikmet Bayur, Türk İnkllâp Tarihi, Cilt:3, Kısım: I, Ankara, 1991, s. 385-386

Zaferin İtmamı, Tasvir-i Efkâr,10 Ocak 1916 (isimsiz makale) 